\title{
Nasopharyngeal Cancer Pathologic Primary Tumor TNM Finding v7
}

National Cancer Institute

\section{Source}

National Cancer Institute. Nasopharyngeal Cancer Pathologic Primary Tumor TNM

Finding v7. NCl Thesaurus. Code C88966.

A pathologic finding about one or more characteristics of nasopharyngeal cancer,

following the rules of the TNM AJCC V7 classification system as they pertain to staging of the primary tumor. 